\title{
STELIS MINIMA SCHENCK, 1859 (HYMENOPTERA: APOIDEA: MEGACHILIDAE) - A SPECIES OF WILD BEE NEW TO POLISH FAUNA
}

\author{
Waldemar Celary ${ }^{*}$, Bogdan Wiśniowski \\ ${ }^{1}$ The Jan Kochanowski University, Institute of Biology, \\ Świętokrzyska 15, 25-406 Kielce, Poland \\ ${ }^{2}$ Ojców National Park, 32-047 Ojców, Poland \\ *corresponding author: waldemar.celary@ujk.edu.pl
}

Received 06 July 2012; accepted 12 January 2013

$\mathrm{S} \mathrm{u} \mathrm{m} \mathrm{m} \mathrm{a} \mathrm{r} \mathrm{y}$

The paper presents information on Stelis minima Schenck, 1859, a species of cleptoparasitic bee new to Polish fauna representing the family Megachilidae. Stelis minima. probably inhabits most of Europe except for the southern and northern parts of the continent. The species was also found in the southern part of Finland, where it reaches its northern range limit $\left(\mathrm{ca} .62^{\circ} \mathrm{N}\right)$. During the years 2002 2006 four specimens of S. minima were collected in the Kraków-Częstochowa Upland (1 male) and Roztocze region ( 2 females and 1 male). All specimens were observed close to nests of probable host species of solitary bees - Chelostoma campanularum (Kirby, 1802) and Heriades truncorum (Linnaeus, 1758). The female of Stelis minima can be distinguished from other Central European species by the following characteristics: rounded head, clypeus about 1.5 times wider than its length, legs black, hind basitarsus almost parallel sided (not broadened on the distal part), distances between punctures on mesopleurae ca. as big as their diameter, posterior margins of metasomal tergites (T) black and without lateral bands of hair, $\mathrm{T}_{1}$ or $\mathrm{T}_{1-2}$ with small, lateral, yellowish white maculae; the maculae are sometimes absent. The male Stelis minima can be separated from other Central European species by the following characteristics: clypeus short (not covering mandibles), legs black, distances between punctures on mesopleurae and tergites $\mathrm{T}_{4-5}$ ca. as big as their diameter, posterior margins of metasomal tergites black and without lateral bands of hair, $T_{1-2}$ or $T_{1-3}$ with small, lateral yellowish white maculae, posterior margin of seventh tergite with short mid-process, posterior margin of third sternite with triangular emargination in the middle, posterior margin of fourth sternite with a tooth-like, mid-process.

Keywords: Hymenoptera, Apoidea, Megachilidae, Stelis minima, new record, distribution, bionomics, Poland.

\section{INTRODUCTION}

The presence of the cleptoparasitic bee, Stelis minima Schenck, 1859, in Poland was a matter of confusion for many authors. Celary (1989) in his review of parasitic bees of the family Megachilidae in Poland, stated that the species had not been recorded in the country so far. Two years later, Banaszak (1991) published a checklist of Polish species and like Stoeckhert (1932), stated that the species was found in Silesia and Pommerania. The same information was repeated by Banaszak (2000) in his following checklist. On the other hand, the key for the identification of Polish megachilid bees listed only Pommerania as the area of occurrence of Stelis minima (Banaszak et al., 2001). Dylewska (1997) like Banaszak (1991) also placed the species on the list of native bees. The source of this confusion was a misinterpretation of what Stoeckhert (1932) wrote in his paper in 1932. He concluded that Stelis minima was not found in Silesia and Pommerania but it was very likely that future investigation would indicate its presence in the regions. 
Stoeckhert's prediction was recently fulfilled, but only partly, as Stelis minima was recorded in Poland, but in other regions of the country.

Imagines of Stelis minima are on wings from the first half of June till the end of July. The species clearly prefers blooming plants of the Asteraceae family. Stelis minima was observed on flowers of Achillea millefolium L. and Tanacetum vulgare L. as well as various species of Inula L. and Hieracium L. (Westrich, 1990). Sometimes this bee also visits flowering plants of the Campanulaceae family, such as Jasione montana L. or some species of Campanula L. (Westrich, 1990) as well as Sedum acre L. of the Crassulaceae family (Elfving, 1968). Females of the cleptoparasitic bee lay their eggs in the nests of other megachilid bees: Chelostoma campanularum (Kirby, 1802) and Ch. distinctum (Stoeckhert, 1929) (Scheuchl, 2006; Westrich, 1990), and Heriades truncorum (Linnaeus, 1758) (Banaszak and Romasenko, 1998).

Stelis minima probably inhabits most of Europe except for the southern and northern parts of the continent. Till now, the species was recorded in Belgium, Luxembourg (Rasmont et al., 1995), Germany, Switzerland, Austria (Schwarz et al., 1996; A miet et al., 2004), the Czech Republic (both Bohemia and Moravia), Slovakia (Straka et al., 2007), the Ukraine, and the European part of Russia (Popov, 1932). Moreover Stelis minima was also found in the southern part of Finland (Elfving, 1968), where it reaches its northern range limit (ca. $\left.62^{\circ} \mathrm{N}\right)$.

The aim of the paper is to give information about the known distribution of Stelis minima in Poland, as well as the diagnosis and redescription of a female and a male of the species (Schenck, 1859).

\section{MATERIAL AND METHODS}

Specimens for the studies were collected during faunistic inventories carried out in the first decade of $21^{\text {st }}$ century. The bees were collected with the use of a sweeping net. All specimens are dry mounted on standard pins. The diagnosis and redescription of the species given in the paper is based on the specimens collected. The measurements were done using Nikon SMZ 1200 stereoscopic microscope with 10x measuring eyepiece; the photographs were taken with a Pixelink microscope camera. Specimens are housed in the collection of B. Wiśniowski. The biology and distribution of Stelis minima are also given.

\section{RESULTS}

The material studied includes 2 females and 2 males collected in the KrakówCzęstochowa Upland and Roztocze region.

Polish localities. Kraków-Częstochowa Upland: DA15 Będkowice Valley, 18.06.2002 - a male on a wooden building, leg. B. Wiśniowski. Roztocze: FB40 Guciów, 6-7.07.2006 - two females and one male on wooden buildings, leg. B. Wiśniowski.

\section{Diagnosis}

The female of Stelis minima can be distinguished from other Central European species by the following characteristics: rounded head, clypeus about 1.5 times wider than its length (Fig. 1), legs black, hind basitarsus almost parallel sided (not broadened on the distal part) (Fig. 2), distances between punctures on mesopleurae ca. as big as their diameter, posterior margins of metasomal tergites black and without lateral bands of hair, $\mathrm{T}_{1}$ or $\mathrm{T}_{1-2}$ with small, lateral, yellowish white maculae (Figs. 3-4); the maculae are sometimes absent. The male Stelis minima can be separated from other Central European species by the following characteristics: clypeus short (not covering mandibles) (Figs. 5-6), legs black, distances between punctures on mesopleurae and tergites $\mathrm{T}_{4-5}$ ca. as big as their diameter, posterior margins of metasomal tergites black and without lateral bands of hair, $\mathrm{T}_{1-2}$ or $\mathrm{T}_{1-3}$ with small, lateral yellowish white maculae, posterior margin of seventh tergite with short midprocess (Fig. 7), posterior margin of third sternite with triangular emargination in the middle, posterior margin of fourth sternite with a tooth-like, mid-process. 


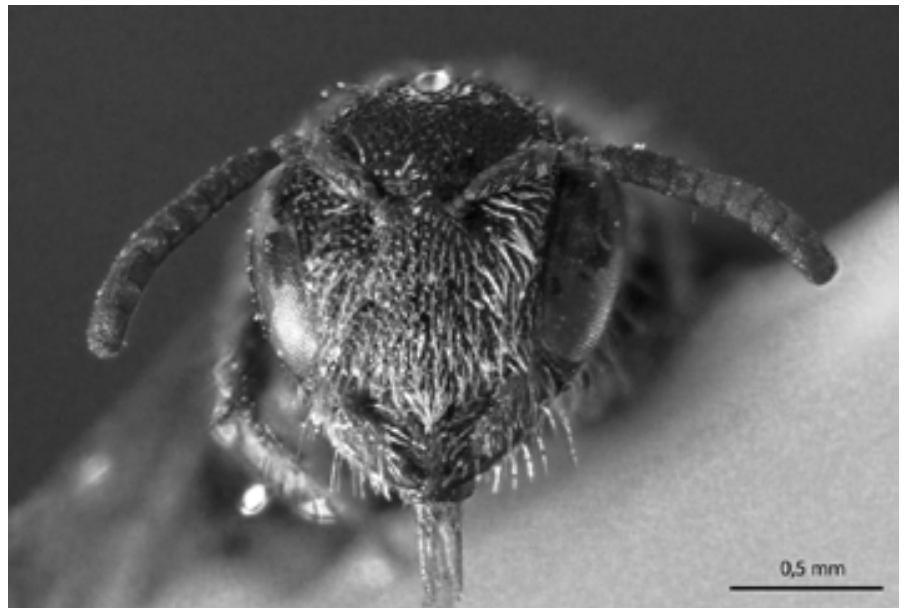

Fig. 1. The head of Stelis minima female (frontal view).

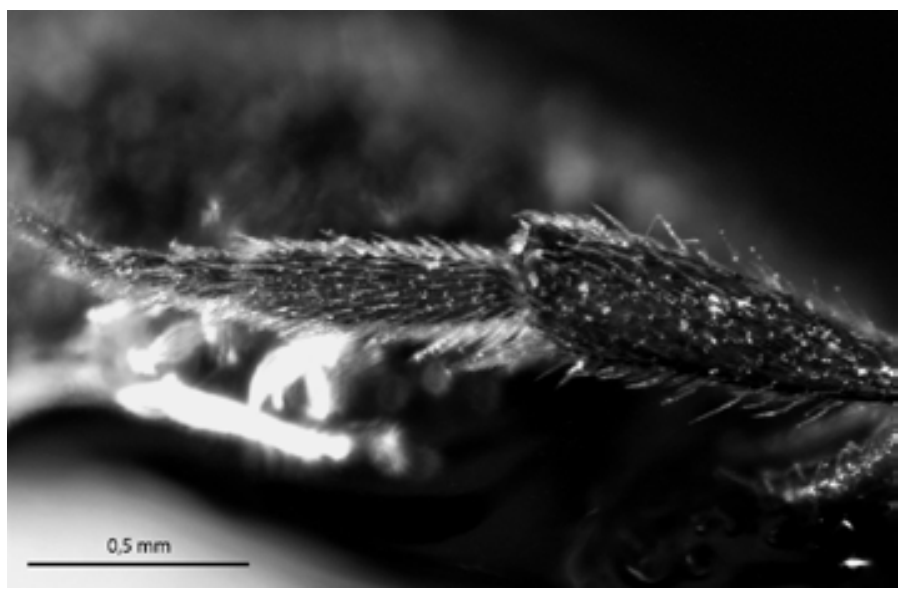

Fig. 2. The hind leg of Stelis minima female (outer view).

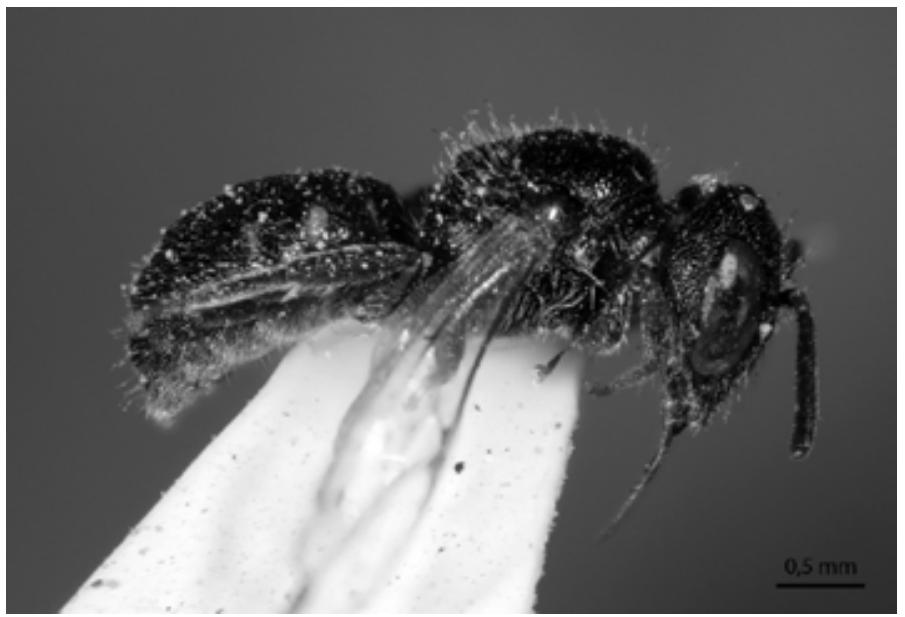

Fig. 3. Female of Stelis minima (lateral view). 


\section{Redescription}

$\mathrm{F}$ e $\mathrm{m}$ a $1 \mathrm{e}$ ( 2 specimens). Measurements and ratios: number of hamuli, 6-8; length of body, 4.2-4.3 mm; length of metasoma (ML), 2.1-2.3 mm; width of metasoma (MW), 1.2-1.3 mm; $\mathrm{ML}: \mathrm{MW}=1: 0.5-0.6$; length of head (HL), 1.2-1.3 mm; width of head (HW), $1.3 \mathrm{~mm}$; HL : HW = $1: 1.0-1.1$; length of face (FL), $1.1 \mathrm{~mm}$; width of face (FW), $0.9 \mathrm{~mm}$; FL : FW = 1: 0.8; length of clypeus (ClL), $0.4 \mathrm{~mm}$; width of clypeus (ClW), $0.6 \mathrm{~mm}$; $\mathrm{ClL}: \mathrm{ClW}=1: 1.5$; length of first flagellomere $\left(\mathrm{Fl}_{1} \mathrm{~L}\right), 0.07-0.08 \mathrm{~mm}$; width of first flagellomere $\left(\mathrm{Fl}_{1} \mathrm{~W}\right)$, $0.09-0.10 \mathrm{~mm} ; \mathrm{Fl}_{1} \mathrm{~L}: \mathrm{Fl}_{1} \mathrm{~W}=1: 1.3$; length of second flagellomere $\left(\mathrm{Fl}_{2} \mathrm{~L}\right), 0.05-0.06 \mathrm{~mm}$; length of third flagellomere $\left(\mathrm{Fl}_{3} \mathrm{~L}\right)$, 0.06-0.07 $\mathrm{mm} ; \mathrm{Fl}_{1} \mathrm{~L}: \mathrm{Fl}_{2} \mathrm{~L}: \mathrm{Fl}_{3} \mathrm{~L}=1$ : $0.7-0.8: 0.9 ; \quad$ width of flagellum $\left(\mathrm{Fl}_{4} \mathrm{~W}\right), 0.12-0.13 \mathrm{~mm}$; length of middle flagellomeres $\left(\mathrm{Fl}_{4-0} \mathrm{~L}\right), \quad 0.09-0.1 \mathrm{~mm}$; $\mathrm{Fl}_{4} \mathrm{~W}: \mathrm{Fl}_{4-9} \mathrm{~L}=1: 0.7-0.8$; length of last flagellomere $\left(\mathrm{Fl}_{10} \mathrm{~L}\right), 0.2 \mathrm{~mm} ; \mathrm{Fl}_{4} \mathrm{~W}: \mathrm{Fl}_{10} \mathrm{~L}$ $=1: 1.5-1.7$; length of malar area (MAL),

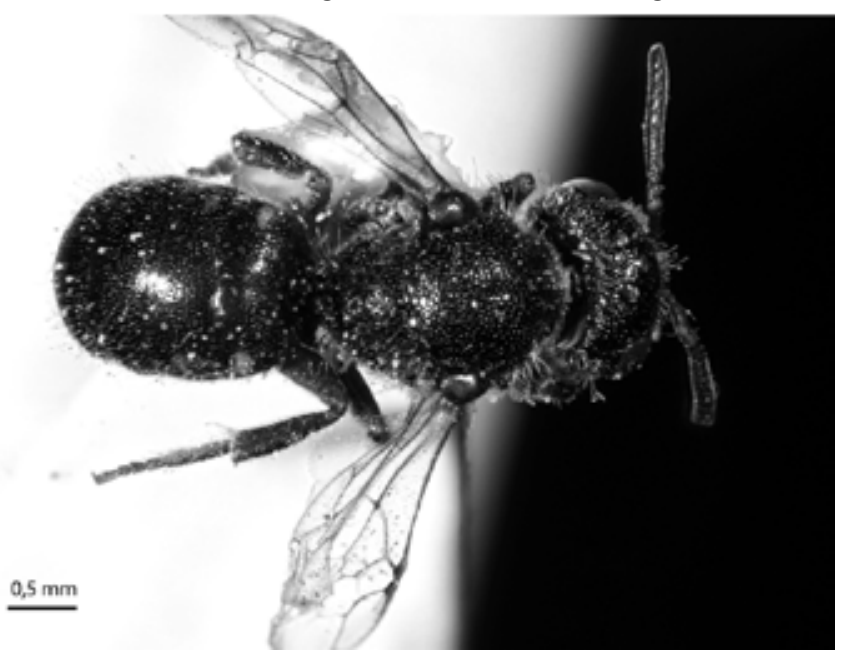

Fig. 4. Female of Stelis minima (dorsal view).

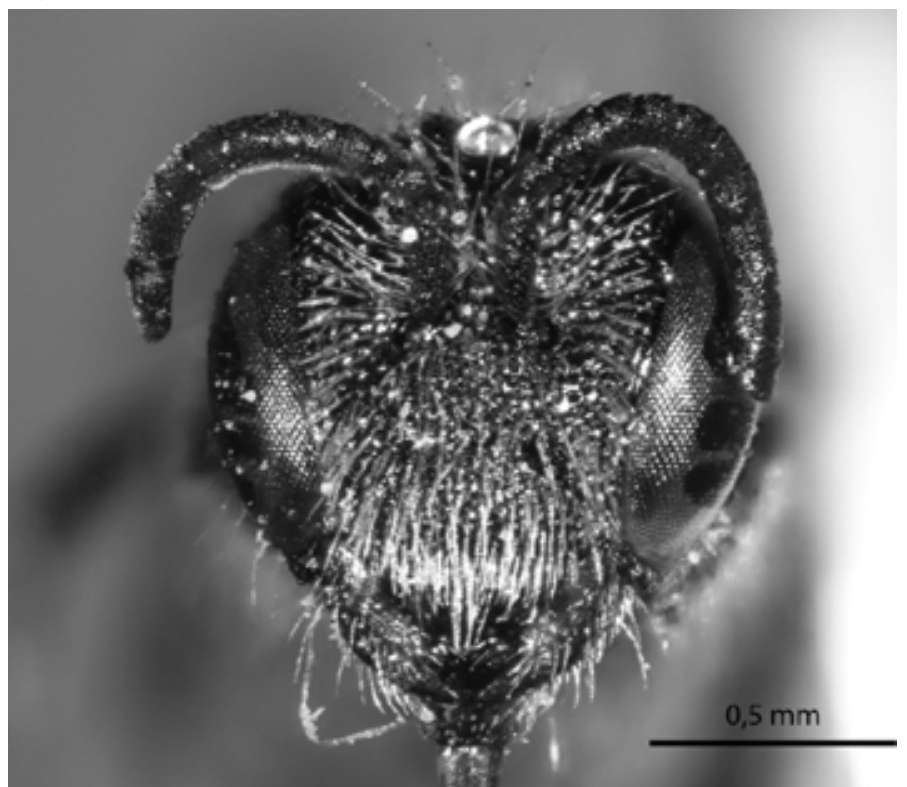

Fig. 5. The head of Stelis minima male (frontal view). 
$0.03 \mathrm{~mm}$; width of malar area (MAW), 0.28-0.29 mm; MAL: MAW = $1: 9-10$.

Structure: head rounded in frontal view, smooth and shiny (spaces between punctures without visible microsculpture), very closely and finely punctured, distance between punctures - $E \leq 0.3$ (value of $E$ as puncture diameter); clypeus short and narrow (about 1.5 times broader than its length), flattened, with almost a straight apical margin; malar area very narrow, almost linear; mandibles tridentate; middle flagellomeres $\left(\mathrm{Fl}_{4-9}\right)$ slightly shorter than broad (Fig. 8); mesosoma smooth and shiny, finely and densely punctured $(E=0.3-1)$, distances between punctures on mesopleurae ca. as much as their diameter; upper margin of propodeal triangle microsculptured with a few very short longitudinal rugulae, remainder of metapostnotum smooth and shiny, rather densely punctured in upper and lateral parts $(E=0.3-1.5)$, and impunctate in the middle; hind basitarsus parallel sided, slender and long, about 4-4.5 times longer than broad; metasoma smooth and shiny, with indistinct microsculpture on $\mathrm{T}_{4-6}$ and
$\mathrm{S}_{3-6}$, punctation of $\mathrm{T}_{1-3}$ somewhat finer and sparser $(E=0.3-3)$ than on $T_{4-6}(E=0.3-2)$, punctation of $\mathrm{S}_{1-2}$ clearly more coarse and sparse $(E=0.3-1)$ than on $S_{3-6}(E<0.3)$.

Integumental colouration: head and mesosoma black, mandibles and antennae brownish, tegulae brownish translucent, legs brownish, tibial spurs whitish translucent, metasoma black with small yellowish white maculae on sides of $T_{1}$ or $\mathrm{T}_{1-2}$ (the maculae are sometimes absent), posterior margins of tergites and sternites brownish translucent.

Pubescence: body rather sparsely covered with grayish white hairs (only hind basitarsi with whitish pubescence); vertex and frons sparsely clothed with short and erect hairs, the remaining parts of the head (supraclypeal area, paraocular areas, genae and clypeus) more densely covered with longer and suberect hairs; dorsum of mesosoma sparsely clothed with short and erect hairs (scutellum and metanotum with somewhat longer and denser pubescence), sides of mesosoma rather sparsely covered with suberect, short hairs; dorsum of metasoma sparsely clothed with short

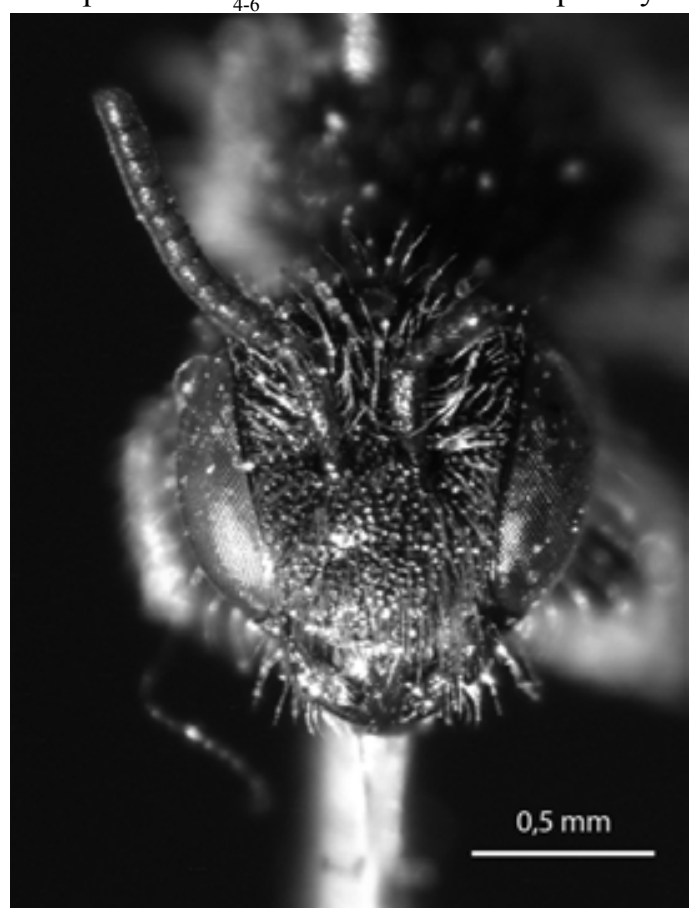

Fig. 6. The head of Stelis minima male (dorsofrontal view). 


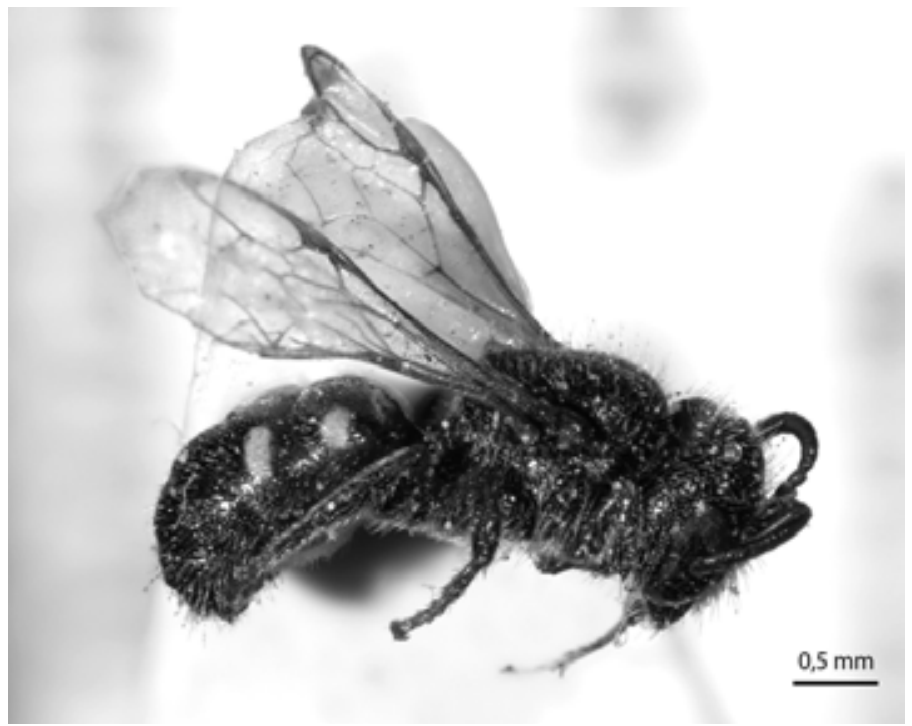

Fig. 7. Male of Stelis minima (lateral view).

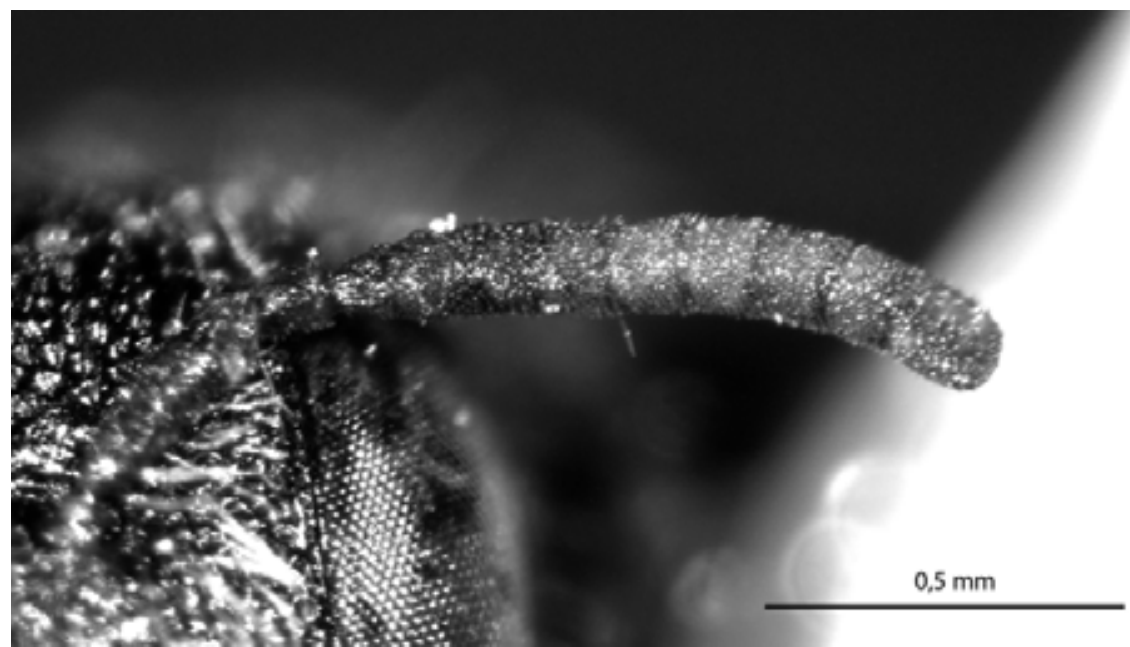

Fig. 8. The antenna of Stelis minima female (dorsal view).

and suberect or erect hairs, sternites rather densely covered with thin and rather short, subappressed hairs; legs - except hind basitarsi - sparsely clothed with short and suberect hairs, hind basitarsi with denser and subappressed pubescence.

$\mathrm{M} \mathrm{a}$ le (2 specimens). Measurements and ratios: number of hamuli, 6-7; length of body, 3.8-4.4mm; lengthofmetasoma(ML), 1.7-1.9 mm; width of metasoma (MW), 1.1-1.3 mm; ML : MW = $1: 0.65-0.68$; length of head (HL), 1.3-1.4 mm; width of head (HW), $1.3 \mathrm{~mm}$; HL : HW = $1: 0.9-1$; length of face (FL), 1.1-1.2 mm; width of face (FW), $0.8 \mathrm{~mm}$; $\mathrm{FL}: \mathrm{FW}=1: 0.7$; length of clypeus $(\mathrm{ClL})$, 0.3-0.4 mm; width of clypeus (ClW), 0.5-0.6 mm; ClL : $\mathrm{ClW}=1: 1.5-1.7$; length of first flagellomere $\left(\mathrm{Fl}_{1} \mathrm{~L}\right), 0.08-0.09 \mathrm{~mm}$; width of first flagellomere $\left(\mathrm{Fl}_{1} \mathrm{~W}\right)$, 0.09-0.10 mm; $\mathrm{Fl}_{1} \mathrm{~L}: \mathrm{Fl}_{1} \mathrm{~W}=1$ : 1.1-1.2; length of second flagellomere $\left(\mathrm{Fl}_{2} \mathrm{~L}\right)$, 0.06-0.07 mm; length of third flagellomere $\left(\mathrm{Fl}_{3} \mathrm{~L}\right), \quad 0.07-0.08 \mathrm{~mm} ; \mathrm{Fl}_{1} \mathrm{~L}: \mathrm{Fl}_{2} \mathrm{~L}$ : 
$\mathrm{Fl}_{3} \mathrm{~L}=1: 0.8: 0.9$; width of flagellum $\left(\mathrm{Fl}_{4} \mathrm{~W}\right)$, $0.12 \mathrm{~mm}$; length of middle flagellomeres $\left(\mathrm{Fl}_{4-10} \mathrm{~L}\right), 0.09-0.10 \mathrm{~mm} ; \mathrm{Fl}_{4} \mathrm{~W}: \mathrm{Fl}_{4-10} \mathrm{~L}$ $=1: 0.8$; length of last flagellomere $\left(\mathrm{Fl}_{11} \mathrm{~L}\right)$, $0.16 \mathrm{~mm} ; \mathrm{Fl}_{4} \mathrm{~W}: \mathrm{Fl}_{11} \mathrm{~L}=1: 1.3$; length of malar area (MAL), $0.03 \mathrm{~mm}$; width of malar area (MAW), 0.24-0.30 mm; MAL : $\mathrm{MAW}=1: 8-10$.

Structure: head elongate to round in frontal view, very closely and rather finely punctured $(E \leq 0.3)$, spaces between punctures smooth and shiny; clypeus short and narrow (about 1.5-1.7 times broader than its length), flattened, with almost straight apical margin (barely visible, very shallow, and narrow emargination in the middle); malar area very narrow (almost linear); middle flagellomeres $\left(\mathrm{Fl}_{4-10}\right)$ slightly shorter than broad; mesosoma smooth and shiny, rather finely (but somewhat coarser than on head) and closely punctured $(\mathrm{E}=0.3-1.5)$, distances between punctures on mesopleurae and tergites $\mathrm{T}_{4-5}$ ca. as big as their diameter; scutellum flat and triangular; propodeal triangle as in female; metasoma smooth and shiny, with very indistinct microsculpture, tergites rather densely punctured $(E=0.3-2)$, punctation of $T_{1-3}$ somewhat finer than on $T_{4-7}$, posterior margin of $\mathrm{T}_{7}$ with short and thin mid-process, sternites closely punctured $(\mathrm{E}=0.3-1), \mathrm{S}_{1-2}$ clearly coarser than $\mathrm{S}_{3-6}$, proximal (basal) part of $\mathrm{S}_{3}$ with flat swelling on sides, $\mathrm{S}_{3}$ shallow emarginated in the middle, posterior margin of $\mathrm{S}_{4}$ with tooth-like process in the middle.

Integumental colouration: head and mesosoma black, mandibles brownish, antennae black to brownish, tegulae brownish translucent, legs brownish or black with brownish medio and distitarsi, tibial spurs whitish translucent, metasoma black with small yellowish white maculae on sides of $T_{1-2}$ (the maculae are sometimes absent), posterior margins of tergites and sternites brownish translucent (sometimes metasomal sternites entirely brownish).

Pubescence: body, except sternites with pubescent, similar to that of female, but somewhat denser and longer; sternites rather densely clothed with thin and rather long, subappressed hairs, middle parts of posterior margins of $\mathrm{S}_{3-4}$ with fimbriae (on $\mathrm{S}_{3}$ continuous, on $\mathrm{S}_{4}$ with a gap in the middle).

\section{CONCLUSIONS}

There are nine species of the genus Stelis Panzer, 1806 known currently from Poland, including Stelis minima Schenck, 1861 redescribed in the paper. The species is known from two remote localities in southern and eastern Poland, but it is probably distributed also in other regions. More research is needed on the species distribution as well as its endangerment status.

\section{REFERENCES}

Amiet F., Herrmann M., Müller A., Neumeyer R. (2004) - Apidae 4. Anthidium, Chelostoma, Coelioxys, Dioxys, Heriades, Lithurgus, Megachile, Osmia, Stelis. Fauna Helv. 9, Neuchâtel, p. 273.

Banaszak J. (1991) - A checklist of the beespecies (Apoidea) of Poland with remarks to their taxonomy and zoogeography. Acta Univ. Lodz., Folia Zool. Anthr., 7: 15-66.

Banaszak J. (2000) - A checklist of the bee species (Hymenoptera, Apoidea) of Poland, with remarks on their taxonomy and zoogeography: revised version. Fragm. Faun., 43(14): 135-193.

Banaszak J., Romasenko L. (1998) Megachilid Bees of Europe (Hymenoptera, Apoidea, Megachilidae). Wyd. uczeln. WSP w Bydgoszczy, Bydgoszcz, p 239.

Banaszak J., Romasenko L., Cierzniak T. (2001) - Pszczołowate - Apidae, Podrodzina: Megachilinae. Klucze do oznaczania owadów Polski, vol. 24, part 68f, Toruń, pp 156.

Celary W. (1989) - Review of the parasitic bees of the family Megachilidae (Hymenoptera, Apoidea) in Poland. Pol. Pismo entomol., 59: 335-355.

Dylewska M. (1997) - Apoidea. [In:] J. Razowski (ed.): Checklist of Animals of Poland. Wyd. Inst. Syst. Ewol. Zwierz. PAN, Kraków, pp. 61-74. 
Elfving R. (1968) - Die Bienen Finnlands. Fauna Fenn., 21: 1-69.

Popov V. B. (1932) - Palearktičeskie formy triby Stelidini Roberts (Hymenoptera, Megachilidae). Trudy Zool. Inst. Acad. Nauk. SSSR, 1: 375-414.

Rasmont P., Ebmer P. A., Banaszak J., van der Zanden G. (1995) - Hymenoptera Apoidea Gallica. Liste taxonomique des abeilles de France, de Belgique, de Suisse et du Grand-Duché de Luxembourg. Bull. Soc. Entomol. France, 100: 1-98.

Schenck A. (1859) - Die nassauischen Bienen. Revision und Ergänzung der früheren Bearbeitungen. Jb. nassau. Ver. Naturk., Wiesbaden, 14: 1-414.

Scheuchl E. (2006) - Illustrierte Bestimmungstabellen der Wildbienen Deutschlands und Österreichs. Band II: Schlüssel der Arten der Familien Magachilidae und Melittidae. 2. erweitere Auflage. Apollo Books, Stenstrup, p. 192.
Schwarz M., Gusenleitner F., Westrich P., Dathe H. H. (1996) Katalog der Bienen Österreichs, Deutschlands und der Schweiz (Hymenoptera, Apidae). Entomofauna, supplement 8, p. 398.

Stoeckhert F. K. (1932) - Die Bienen Frankens. Eine ökologisch-tiergeographische Untersuchung. Dtsch. Entomol. Z., Beiheft, p. 294.

Straka J., Bogusch P., Přidal A. (2007) Apoidea: Apiformes (včely), in: J. Straka, P. Bogusch, P. Kment (Eds.): Annotated checklist of the Aculeata (Hymenoptera) of the Czech Republik and Slovakia. Acta Entomol. Mus. Nation. Pragae, supplementum 11: 241-299.

Westrich P. (1990) - Die Wildbienen BadenWürttembergs. Spezieller Teil: Die Gattungen und Arten, Eugen Ulmer GmbH \& Co., Stuttgart, p. 535.

\title{
STELIS MINIMA SCHENCK, 1859 (HYMENOPTERA: APOIDEA: MEGACHILIDAE) - NOWY GATUNEK DZIKIEJ PSZCZOLY DLA FAUNY POLSKI
}

\author{
Celary W., Wiśniowski B.
}

\author{
$\mathrm{S} t \mathrm{r}$ e s z c z e n i e
}

Artykuł informuje o Stelis minima Schenck, 1859, nowym dla fauny Polski gatunku kleptopasożytniczej pszczoły z rodziny miesierkowatych (Megachilidae). Stelis minima. zamieszkuje prawdopodobnie większą część Europy, za wyjątkiem jej części południowej i północnej; najdalej na północ położone stanowiska znane są z południowej Finlandii (około $62^{\circ} \mathrm{N}$ ).W latach 2002-2006 odłowiono 4 okazy tego gatunku, w tym 1 na Wyżynie Krakowsko-Częstochowskiej i 3 na Roztoczu. Wszystkie okazy przebywały na drewnianych budynkach, w sąsiedztwie gniazd potencjalnych gatunków żywicielskich - Chelostoma campanularum (Kirby, 1802) i Heriades truncorum (Linnaeus, 1758). Samica Stelis minima charakteryzuje się następującymi cechami morfologicznymi, które ją odróżniają od innych gatunków środkowoeuropejskich: głowa zaokrąglona, nadustek około 1,5 raza szerszy niż jego długość, nogi czarne, nadstopie tylnych nóg o niemal równoległych bokach (nie rozszerzone w końcowej części), odległości pomiędzy punktami na śródbocznych częściach tułowia mniej więcej równe ich średnicy, tylne brzegi tergitów metasomy czarne, pozbawione bocznych przepasek z włosków, pierwszy i drugi tergit zazwyczaj z małymi, żółtawo-białymi plamami położonymi po bokach (plam czasem brak). Samce Stelis minima różnią się od innych środkowoeuropejskich gatunków następującą kombinacją cech morfologicznych: nadustek krótki (żuwaczki nie są pod nim schowane), nogi czarne, odległości pomiędzy punktami na śródbocznych częściach tułowia oraz czwartym i piątym tergicie mniej więcej równe ich średnicy, 
tylne brzegi tergitów metasomy czarne, pozbawione bocznych przepasek z włosków, pierwszy i drugi tergit (czasem też trzeci) z małymi, żółtawo-białymi plamami położonymi po bokach, tylny brzeg trzeciego sternitu z trójkątnym obrzeżeniem pośrodku, tylny brzeg czwartego sternitu pośrodku z niewielkim wyrostkiem w kształcie ząbka.

Słowa kluczowe: Hymenoptera, Apoidea, Megachilidae, Stelis minima, nowe stwierdzenie, redeskrypcja, bionomia, Polska. 